\title{
Laboratory Assessment of the Hypertensive Individual. Value of the Main Guidelines for High Blood Pressure
}

\author{
Rafael S. Reis, Isabela J. Benseñor, Paulo A. Lotufo \\ São Paulo, SP - Brazil
}

Objective - To determine if abnormal laboratory findings are more common in individuals with hypertension and in those with other risk factors, such as obesity, smoking and alcohol ingestion.

Methods - A study was carried out in the general outpatient clinics of a university hospital (145 individuals without previous diagnosis of hypertension) and the following variables were assessed: high blood pressure (as defined by the VIJoint National Committee on Prevention, Detection and Treatment of High Blood Pressure -VI $J N C$ ), obesity [calculated using body mass index (BMI)], tobacco use, and alcoholic ingestion. The laboratory examinations consisted of the following tests: hemogram, glycemia, uric acid, potassium, total/HDL-fraction cholesterol, triglycerides, calcium and creatinine.

Results - High blood pressure was not associated with a higher number of abnormal laboratory tests. Hypertensive individuals with a $B M I \geq 25 \mathrm{~kg} / \mathrm{m}^{2}$ or normotensive obese individuals, however, had a higher frequency of diabetes $(12 X)$, hypertriglyceridemia $(3 X)$, and hypercholesterolemia $(2 X)$, as compared with hypertensive individuals with $B M I<25 \mathrm{~kg} / \mathrm{m}^{2}$ and preobese/normal weight normotensive individuals.

Conclusion - High blood pressure is not associated with a higher frequency of abnormal laboratory tests. The association of high blood pressure and obesity, however, increases the detection of diabetes and dyslipidemias.

Keywords: laboratory examinations, high blood pressure, obesity, screening

Faculdade de Medicina da Universidade de São Paulo

Mailing address: Rafael S. Reis - Faculdade de Medicina da USP - Disciplina de Clínica Geral - Av. Dr. Arnaldo, 455 - S/1216 - 01246-000 - São Paulo, SP, Brazil Received on $1 / 4 / 99$

Accepted on $7 / 15 / 99$
The high prevalence of hypertension in Brazil ${ }^{1}$ has an impact on early cardiovascular mortality rates, which are among the highest in the world ${ }^{2}$. The proposals for management of hypertensive patients, such as those presented at the II Consenso Brasileiro em Hipertensão Arterial (II CBHA) ${ }^{3}$ and in the VI Joint National Committee on Prevention, Detection and Treatment of High Blood Pressure (VI $\mathrm{JNC})^{4}$, are of great importance.

These guidelines comprise recommendations for laboratory tests to be performed in individuals with confirmed high blood pressure (BP). The II CBHA proposes the study of urinary sediment, the dosage of creatinine and potassium in the serum, fasting glycemia, total cholesterol (men $>20$ years of age and menopausal women with total cholesterol $>200 \mathrm{mg} /$ $\mathrm{dL}$, in addition to the remaining lipid fractions), and an electrocardiogram. The examinations considered mandatory by the VIJNC are the above-cited ones in addition to a complete red and white cell counts and an HDL (high-density lipoprotein)-cholesterol fraction profile and the optional dosage of serum calcium and uric acid.

Along with the diagnosis of high blood pressure, however, other significant diagnoses in the risk assessment may be made, such as that of obesity, which is calculated using body mass index (BMI), and those of alcoholism and tobacco use, through a clinical history. As the management of the hypertensive individual aims to reduce cardiovascular risk, it should address these other risk factors, along with hypertension, allowing the establishment of actions with higher effectiveness and rationality in the use of the resources.

The objective of this study is to assess the routine use of blood tests in hypertensive patients, considering the possibility of the association of other diagnoses, such as obesity, tobacco use and alcoholism, evaluated at the same medical appointment.

\section{Methods}

We studied 145 individuals without a previous diagnosis of high BP, heart or any other chronic disease (liver, 
kidney or rheumatic disease, or cancer). These individuals spontaneously and consecutively searched for medical care in the Internal Medicine outpatient clinics of a tertiary university hospital in a urban center, with diverse complaints on the same day of the week, over a period of 2 months. All patients answered a questionnaire on the current use of alcohol and cigarettes, and underwent blood withdrawal after giving written consent.

In all individuals, weight and height were measured with an anthropometric scale and the patients wearing lightweight clothing. The BMI was obtained by dividing the weight (in $\mathrm{kg}$ ) by the square of the height (in $\mathrm{m}^{2}$ ). According to the definitions of the World Health Organization for obesity ${ }^{5}$, the patients were classified as follows: normal weight $\left(\mathrm{BMI}<25 \mathrm{~kg} / \mathrm{m}^{2}\right)$, preobese $\left(\mathrm{BMI} \geq 25 \mathrm{~kg} / \mathrm{m}^{2}\right.$ and $\left.<30 \mathrm{~kg} / \mathrm{m}^{2}\right)$ and obese $\left(\mathrm{BMI} \geq 30 \mathrm{~kg} / \mathrm{m}^{2}\right)$.

Blood pressure was measured by a trained nurse according to the recommendations of the II CBHA, with a mercury sphygmomanometer. Two blood pressure readings were taken more than 15 minutes apart on each arm with the patient sitting and supine, which was considered the second measure. The individuals were then classified as hypertensive or normotensive according to the definition of the II CBHA and of the VIJNC (hypertensive individuals: systolic pressure $\geq 140 \mathrm{mmHg}$ or diastolic pressure $\geq 90 \mathrm{mmHg}$ ).

Biochemical tests and the hemogram were performed according to automated methods in the central laboratory of the hospital, in the morning, after a 12-hour fasting period. The classification of lipid disorders followed the proposal of the I Consenso BrasileiroSobre Dislipidemias: Detecção, Avaliaçãoe Tratamento ${ }^{6}$ : normal cholesterol $(<200 \mathrm{mg} / \mathrm{dL})$, intermediate values of cholesterol (between $200 \mathrm{mg} / \mathrm{dL}$ and $239 \mathrm{mg} / \mathrm{dL}$ ) and high cholesterol $(\geq 240 \mathrm{mg} / \mathrm{dL})$; and desired levels of triglycerides $(<200 \mathrm{mg} / \mathrm{dL}$ ) orelevated levels of triglycerides $(\geq 200 \mathrm{mg} / \mathrm{dL})$. The diagnosis of diabetes was made when glycemia was higher than $126 \mathrm{mg} / \mathrm{dL}$ in only one dosage, according to the definition of the American Diabetes Society ${ }^{7}$. Some diagnoses based on the other examinations were assessed, such as anemia (hemoglobin $<12 \mathrm{~g} / \mathrm{dL})$, elevated creatinine $(>1.4 \mathrm{mg} / \mathrm{dL})$, hypopotassemia
( $<3.5 \mathrm{mEq} / \mathrm{L}$ ), hyperpotassemia $(>5.5 \mathrm{mEq} / \mathrm{L}$ ), hyperuricemia(uric acid $>7.0 \mathrm{mg} / \mathrm{dL})$, and hypercalcemia $(>5.5 \mathrm{mEq} / \mathrm{L})$.

After confirming the diagnosis of high blood pressure, the differences in sex, age, and BMI, obesity, tobacco use and alcoholism were analyzed as well as were the values of the laboratory tests and the frequency of the different diagnoses resulting from these tests. Then, reclassifying the same population according to the values of BMI, the association of the variable obesity with the remaining tests was assessed. The same procedure was repeated for tobacco and alcohol use. Tobacco use was analyzed comparing the differences between smokers and nonsmokers in the last year. The use of alcohol was analyzed dividing the participants into a group who ingested alcohol once or more a week and another group drinking it less than once a week. Finally, the values of blood pressure and BMI were used to classify the participants into two groups: low-risk group, including the normotensive individuals with BMI $<30 \mathrm{~kg} / \mathrm{m}^{2}$ (normal and preobese) and the hypertensive individuals with normal weight and, the high-risk group, encompassing the normotensive individuals with BMI $\geq 30 \mathrm{~kg} / \mathrm{m}^{2}$ (obese) and the hypertensive individuals with $B M I \geq 25 \mathrm{~kg} / \mathrm{m}^{2}$ (preobese and obese).

The statistical analysis for continuous variables was performed using the Student's $t$ test, analysis of variance and multiple linear regression, and for the categorical variables the chi-square test (the Cochran-Mantel-Haenszel test for the linear trend or the Fischer exact test, when indicated). A cut point was not established for the values of $\mathrm{P}$, which was presented as calculated. For the statistical analysis, the SAS software for personal computers was employed (The SAS System for Windows. Release 6.12. TS Level 0020. SAS Institute Inc., Cary, NC, USA).

\section{Results}

The characteristics of the participants according to the definition of high blood pressure by the II CBHA and the VI JNC are shown in table I. Women, without differences between the 2 groups, comprised almost $75 \%$ of the sample. The hypertensive individuals were older and more

\begin{tabular}{|c|c|c|c|}
\hline & $\begin{array}{l}\text { Normotensive ind. } \\
\qquad(\mathrm{n}=76)\end{array}$ & $\begin{array}{l}\text { Hypertensive ind. } \\
\qquad(\mathrm{n}=69)\end{array}$ & $\mathrm{P}$ \\
\hline Sex, male/female & $20 / 56$ & $17 / 52$ & 0.817 \\
\hline Age, years ${ }^{\dagger}$ & $47.0 \pm 6.0$ & $49.0 \pm 4.7$ & 0.0272 \\
\hline Systolic pressure, $\mathrm{mmHg}^{\dagger}$ & $117.0 \pm 10.9$ & $148.8 \pm 8.6$ & 0.0001 \\
\hline Diastolic pressure, $\mathrm{mmHg}^{\dagger}$ & $75.8 \pm 7.0$ & $93.6 \pm 3.9$ & 0.0001 \\
\hline Alcohol ingestion, $\geq 1$ once a week, $\%$ & 15.8 & 13.4 & 0.639 \\
\hline Smokers, $\%$ & 36.8 & 30.4 & 0.415 \\
\hline Body mass index, $\mathrm{kg} / \mathrm{m}^{2 \dagger}$ & $24.1 \pm 4.3$ & $26.4 \pm 5.0$ & 0.0035 \\
\hline Normal weight $\left(<25 \mathrm{~kg} / \mathrm{m}^{2}\right), \%$ & 63.2 & 33.3 & \\
\hline Preobese individuals, $\left(25-29.9 \mathrm{~kg} / \mathrm{m}^{2}\right), \%$ & 30.3 & 49.3 & \\
\hline Obese individuals $\left(\geq 30 \mathrm{~kg} / \mathrm{m}^{2}\right), \%$ & 6.8 & 17.4 & $0.001^{\ddagger}$ \\
\hline $\begin{array}{l}\text { * Criteria of the II Consenso Brasileiro em } \\
\text { Blood Pressure for the diagnosis of high } \\
\text { Mantel-Haenszel test for linear trend (corr }\end{array}$ & $\begin{array}{l}\mathrm{d} \text { of the VI Joint Nati } \\
\text { pressure } \geq 140 \mathrm{mmH} \\
\text { ero). }\end{array}$ & $\begin{array}{l}\text { tion, Detection, Eval } \\
\text { OmmHg. } \dagger \text { mean } \pm \mathrm{s}\end{array}$ & $\begin{array}{l}t \text { of High } \\
\text { Cochran- }\end{array}$ \\
\hline
\end{tabular}


obese than the normotensive individuals. A significant difference of BMI between the two groups persisted even after adjusting for age. The current use of cigarettes and the frequency of ingestion of alcohol were similar for both groups.

Table II shows the mean values of the laboratory tests and the diagnoses resulting from them. The mean values for glycemia, triglycerides, total and HDL cholesterol were similar in both groups. None of the biochemical tests showed any difference in the proportion of altered values in the two groups. The diagnoses of hyperuricemia and hypercalcemia were also similar for hypertensive and control individuals. Hypo- or hyperpotassemia and creatinine levels $>1.4 \mathrm{mg}$ / $\mathrm{dL}$ (values not corrected for body surface and age) were not found in any of the groups.

Alcohol ingestion was only associated with two variables: mean corpuscular volume and uric acid. The current use of tobacco did not correlate with any of the tests performed, except for a significant increase in leukocytes (data not shown).

Reclassification of the same population according to the values of BMI did not show any sex or age difference, when the diagnosis of obesity was considered (table III). As expected, the frequency of tobacco use among the thinnest individuals is three times higher as compared with that of the obese individuals. Glycemia and triglyceride levels and, consequently, the diagnoses of diabetes and hypertriglyceridemia relate directly to obesity. The frequency of diabetes was 7 times higher in the obese individuals as compared with the thin individuals.

Table IV shows the characteristics of the individuals and laboratory tests according to a combination of the diagnoses of high blood pressure and obesity. There was no difference with regards to sex, age, tobacco and alcohol use in both groups. The diagnosis of diabetes was almost 13 times more frequent and the values of the triglycerides (3 times) and cholesterol (2 times) were significantly more elevated in the high-risk group.

\section{Discussion}

In a sample of middle-aged individuals, who spontaneously sought medical care in a tertiary hospital, the diagnosis of high blood pressure was not associated with any alteration in the blood tests recommended by the II CBHA and the VI JNC. High blood pressure, however, was strongly associated with obesity, which when analyzed separately correlated with diabetes and high levels of triglycerides. The combined analysis of high blood pressure and obesity identified a group (normotensive individuals with BMI $\geq 30 \mathrm{~kg}$ / $\mathrm{m}^{2}$ or hypertensive individuals with a BMI $\geq 25 \mathrm{~kg} / \mathrm{m}^{2}$ ) with higher frequency of diagnosis of diabetes, and elevated levels of triglycerides and cholesterol.

The introduction of mandatory laboratory tests based only on the diagnosis of hypertension is not justifiable. The conjunct assessment of high blood pressure and obesity (more accurately diagnosed than high blood pressure), however, allows a rationalization in the indication and followup of high-risk patients, mainly those patients with diabetes and elevated levels of cholesterol and triglycerides.

Tobacco use did not indicate the search for any test that might impact cardiovascular risk; diagnosis of this condition, however, is fundamental, because it is associated with a higher risk of death and events such as myocardial infarction and cancer than the high blood pressure itself ${ }^{8}$. Diagnosis of alcoholism also did not indicate the performance of any test that could impact cardiovascular risk, except for the presence of elevated levels of uric acid, whose

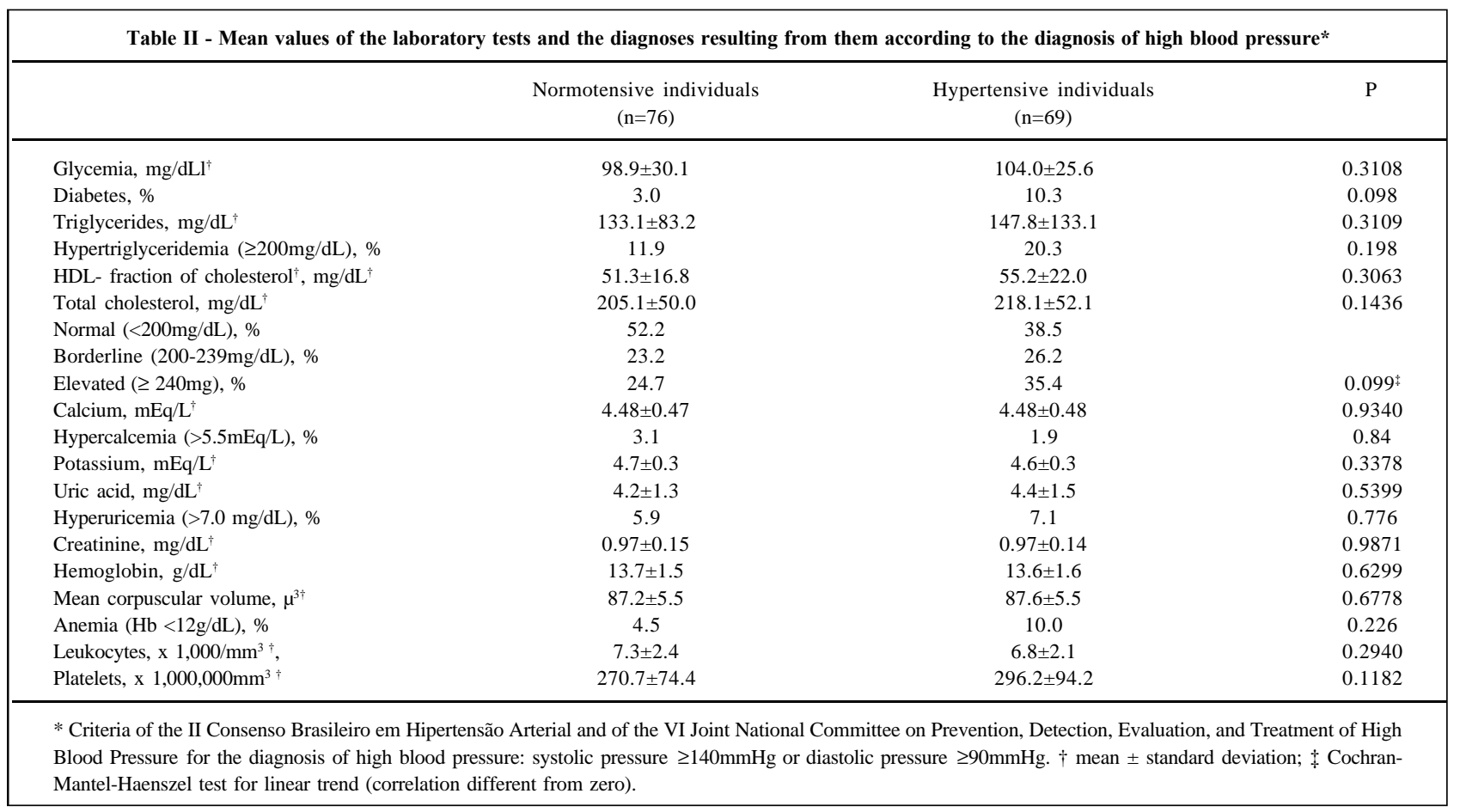




\begin{tabular}{|c|c|c|c|c|}
\hline \multicolumn{5}{|c|}{ Table III - Characteristics and laboratory tests according to the diagnosis of obesity* } \\
\hline & $\begin{array}{c}\text { Normal } \\
(n=71)\end{array}$ & $\begin{array}{c}\text { Preobese } \\
\text { individuals } \\
\quad(n=57)\end{array}$ & $\begin{array}{c}\text { Obese } \\
\text { individuals } \\
(\mathrm{n}=17)\end{array}$ & $\mathrm{P}$ \\
\hline Body mass index $\left(\mathrm{kg} / \mathrm{m}^{2}\right)$ & $<25.0$ & $25.0-29.9$ & $\geq 30$ & \\
\hline Sex, male/female & $18 / 53$ & $14 / 43$ & $5 / 12$ & 0.921 \\
\hline Age, years & $47.2 \pm 5.3$ & $48.7 \pm 5.3$ & $48.2 \pm 6.2$ & 0.2659 \\
\hline Body mass index, $\mathrm{kg} / \mathrm{m}^{2}$ & $21.7 \pm 1.9$ & $26.6 \pm 1.3$ & $35.2 \pm 3.6$ & 0.0001 \\
\hline Alcohol ingestion, $\geq$ once a week, $\%$ & 16.9 & 10.5 & 17.6 & 0.551 \\
\hline Smokers, $\%$ & 45.1 & 24.6 & 17.7 & 0.017 \\
\hline Glycemia, mg/dL & $94.6 \pm 10.6$ & $104.1 \pm 27.0$ & $135.2 \pm 3.6$ & 0.0064 \\
\hline Diabetes, $\%$ & 1.7 & 9.8 & 14.3 & 0.036 \\
\hline Triglycerides, $\mathrm{mg} / \mathrm{dL}^{\dagger}$ & $113.9 \pm 52.1$ & $160.2 \pm 85.2$ & $180.2 \pm 128.3$ & 0.0012 \\
\hline Hypertriglyceridemia $(\geq 200 \mathrm{mg} / \mathrm{dl}), \%$ & 4.9 & 23.6 & 35.7 & 0.001 \\
\hline HDL-fraction of cholesterol ${ }^{\dagger}, \mathrm{mg} / \mathrm{dL}$ & $55.8 \pm 20.9$ & $48.5 \pm 17.5$ & $56.3 \pm 12.9$ & 0.136 \\
\hline Total cholesterol ${ }^{\dagger}, \mathrm{mg} / \mathrm{dL}$ & $224.9 \pm 55.4$ & $216.5 \pm 53.2$ & $203.5 \pm 47.9$ & 0.2025 \\
\hline Normal $(<200 \mathrm{mg} / \mathrm{dL}), \%$ & 55.6 & 35.2 & 41.2 & \\
\hline Borderline $(200-239 \mathrm{mg} / \mathrm{dL}), \%$ & 19.1 & 33.3 & 17.7 & \\
\hline Elevated $(\geq 240 \mathrm{mg}), \%$ & 25.4 & 31.5 & 41.2 & $0.0086^{+}$ \\
\hline
\end{tabular}

\begin{tabular}{|c|c|c|c|}
\hline & $\begin{array}{c}\text { Low risk } \\
(\mathrm{n}=94)\end{array}$ & $\begin{array}{l}\text { High risk } \\
\quad(\mathrm{n}=51)\end{array}$ & $\mathrm{P}$ \\
\hline Sex, male/female & $24 / 70$ & $13 / 38$ & 0.996 \\
\hline Age, years ${ }^{\dagger}$ & $47.0 \pm 4.9$ & $49.5 \pm 6.0$ & 0.0128 \\
\hline Systolic pressure, $\mathrm{mmHg}^{\dagger}$ & $125.2 \pm 17.3$ & $145.0 \pm 4.1$ & 0.0001 \\
\hline Diastolic pressure, $\mathrm{mmHg}^{\dagger}$ & $80.8 \pm 10$ & $90.6 \pm 8.7$ & 0.0001 \\
\hline Body mass index, $\mathrm{kg} / \mathrm{m}^{2 \dagger}$ & $22.9 \pm 2.9$ & $29.6 \pm 4.8$ & 0.0001 \\
\hline Alcohol ingestion, $\geq$ once a week, $\%$ & 14.9 & 13.7 & 0.849 \\
\hline Smokers, $\%$ & 37.2 & 27.5 & 0.234 \\
\hline Glycemia, mg/dL ${ }^{\dagger}$ & $94.9 \pm 10.9$ & $113.5 \pm 43.1$ & 0.0079 \\
\hline Diabetes, $\%$ & 1.2 & 16.3 & 0.001 \\
\hline Triglycerides, $\mathrm{mg} / \mathrm{dL}^{\dagger}$ & $123.3 \pm 63.9$ & $171.2 \pm 99.9$ & 0.0054 \\
\hline Hypertriglyceridemia ( $\geq 200 \mathrm{mg} / \mathrm{dL}), \%$ & 9.8 & 27.3 & 0.010 \\
\hline HDL-fraction of cholesterol ${ }^{\dagger}, \mathrm{mg} / \mathrm{dL}^{\dagger}$ & $53.8 \pm 21.2$ & $51.1 \pm 14.1$ & 0.4317 \\
\hline Total cholesterol, $\mathrm{mg} / \mathrm{dL}^{\dagger}$ & $202.1 \pm 48.3$ & $228.0 \pm 52.7$ & 0.0060 \\
\hline Normal (<200 mg/dL), \% & & 53.5 & 31.3 \\
\hline Borderline $(200-239 \mathrm{mg} / \mathrm{dL}), \%$ & 23.3 & 27.1 & \\
\hline Elevated $(\geq 240 \mathrm{mg}), \%$ & 23.3 & 41.7 & $0.008 \ddagger$ \\
\hline
\end{tabular}

value as a cardiovascular risk factor is questionable ${ }^{9}$. An increased level of the HDL-fraction of cholesterol in individuals who used to drink alcohol frequently was not detected. The red cell count, however, was sensitive enough to show differences in the value of the mean corpuscular volume of the red blood cells, a classical laboratory alteration in alcoholism. The diagnosis of alcoholism is important because this condition is a risk factor for high blood pressure ${ }^{10}$. The protective effect of alcohol for coronary heart disease (but not for cerebrovascular disease), even though representing an important piece of epidemiological knowledge, can not be considered in individual medical actions, and even less so in those of public health ${ }^{11}$.

The present study only recommends laboratory tests within criteria of risk stratification, with evident advantages in prioritizing activities and economy of resources. The cost of the laboratory tests for the Sistema Unificado de Saúde (SUS) - Unified Health System - from July 97 to June 98 was 46 million reais ${ }^{12}$. This is an underestimated value considering that a large part of the exams were performed using resources other than those of the SUS. Other factors should be considered, such as indirect costs, including loss of working hours due to collection of material, personal costs, and the false-positive fraction of the exams, triggering an infinity of other exams. In addition, there is the discomfort of the patient due to the venous puncture and the risk of transportation for the people working at the basic health units.

This study aimed to evaluate the impact of a set of laboratory tests on individuals with the diagnosis of high blood pressure; it was not designed to identify risk factors for high blood pressure, as in other studies ${ }^{13-18}$. In this sample, however, a strong association between body weight and 
blood pressure was identified, and this fact was confirmed in a series of Brazilian studies with a population base ${ }^{19-21}$ and through an evaluation of a program of prevention of cardiovascular diseases in the basic health network ${ }^{22}$. One limitation of the present study is the hospital sample and its size and also the absence of the measurement of the waist and hip circumferences, which may be another important tool for stratifying risk ${ }^{21}$. All the individuals studied, however, were classified as mild or intermediate hypertensive individuals, and these are the most common diagnoses in most patients who use the basic health units. Even though in the outpatient care unit, where these patients were studied, the complaints were simple (chronic and referred patients were excluded), there was an unavoidable effect of attraction of more critical and complex patients, as compared with the patients of the basic health network. The number of patients examined represents approximately the number of new cases without previous cardiovascular disease managed by a single physician in a basic health unit in 3 months. These factors, however, only emphasize the findings that the perfor- mance of routine blood tests determined only by the fact that the patient has high blood pressure is unnecessary.

The present study points out to the need for another study with a larger sample in regard to territorial extension and age range, which will allow the analysis of factors such as direct cost and expenditures resulting from the false-positive examinations. They will also provide a better understanding of the synchronism of risk factors and intervention based on a stratified analysis of the risk ${ }^{23}$.

In conclusion, the present study of hypertensive individuals managed for the first time in a tertiary hospital shows that, without any other clinical suspicion, the performance of routine tests for isolated hypertension is not necessary. When the diagnosis of obesity is associated with that of hypertension, hypertensive individuals with BMI $\geq 25 \mathrm{~kg} / \mathrm{m}^{2}$ (as for normotensive individuals with BMI $\geq 30 \mathrm{~kg} / \mathrm{m}^{2}$ ), the assessment of glycemia, total cholesterol and triglycerides was advantageous. In public health activities, the programs of hypertension must perform the diagnosis of obesity and prioritize the detection of diabetes and dyslipidemias in these patients.

\section{References}

1. Lessa I, Mendonça GA, Teixeira MT. Doenças crônicas não-transmissíveis no Brasil: dos fatores de risco ao impacto social. Boletim da Oficina Sanitária Panamericana, 1996: 120: 389-413.

2. Lotufo PA. Mortalidade prematura por doenças do coração no Brasil. Comparação com outros países. Arq Bras Cardiol 1988; 70: 321-5.

3. Segundo Consenso Brasileiro Para o Tratamento da Hipertensão Arterial. Arq Bras Cardiol 1994; 63.

4. Sixth report of the Joint National Committee on prevention, detection, evaluation, and treatment of high blood pressure. Arch Intern Med 1997; 157: 2413-46.

5. Report of a WHO Consultation on Obesity. Obesity: Preventing and Managing the Global Epidemic. Geneva: WHO/NUT/NCD/98: 1997: 1.

6. Segundo Consenso Brasileiro sobre Dislipidemias: Detecção, Avaliação e Tratamento. Arq Bras Cardiol 1996; 67: 109-28.

7. Expert Committee on The Diagnosis and Classification of Diabetes Mellitus. Report of the The Expert Committee on the Diagnosis and Classification of Diabetes Mellitus. Diabetes Care 1997; 20: 1183-97.

8. Peto R, Lopez AD, Boreham J, Thun M, Heath C Jr. Mortality from tobacco in developed countries: indirect estimation from national vital statistics Lancet 1992; 23: 1268-78.

9. Brand FN, McGee DL, Kannel WB, Stokes J, Castelli WP. Hyperucemia as a risk factor of coronary heart disease: The Framingham Study. Am J Epi 1985; 121: 11-18.

10. Intersalt Cooperative Research Group. Intersalt: an international study of electrolyte excretion and blood pressure. Results for 24 hour urinary sodium and potassium excretion. Br Med J 1988; 297: 319-28.

11. Stampfer MJ, Rimm EB, Chapman-Walsh D. Alcohol, the Heart, and Public Policy. Am J Public Health 1993; 83: 801-04.

12. Sistema de Informação Ambulatorial do Sistema Unificado de Saúde, 1998. Rio de Janeiro: Datasus.
13. Costa EA. A cross-seccional survey of blood pressure in Rio Grande do Sul, Brazil. Londres, 1981 (PhD Thesis Faculty of Medicine - University of London).

14. Klein CH. Araújo JW. Leal MC. Inquérito epidemiológico sobre hipertensão arterial em Volta Redonda (RJ). Cad Saúde Pública 1985; 1: 8-70.

15. Duncan BB, Schmidt MI, Polanczyk CA. Homrich CS, Rosa RS, Achutti AC. Fatores de risco para doenças não-transmissíveis em área metropolitana no sul do Brasil. Prevalência e simultaneidade. Rev Saúde Pública 1993; 27: 43-8.

16. Lolio CA, Pereira JC, Lotufo PA, Souza JM. Hipertensão arterial e possíveis fatores de risco. Rev Saúde Pública 1993; 27: 357-62.

17. Piccini RX, Victora CG. Hipertensão arterial sistêmica em área urbana do sul do Brasil: prevalência e fatores de risco. Rev Saúde Pública 1994; 28: 261-7.

18. Fuchs FD, Moreira LB, Moraes RS, Bredemeier M, Cardozo SC. Prevalência da hipertensão arterial sistêmica e fatores de risco associados na área metropolitana de Porto Alegre. Arq Bras Cardiol 1994; 63: 473-9.

19. Bloch KV, Klein CH, Souza e Silva NA, Nogueira AR, Campos LH. Hipertensão arterial e obesidade na Ilha do Governador, Rio de Janeiro. Arq Bras Cardiol 1994; 62: 17-22.

20. Pozzan R, Brandão AA, Silva SL, Brandão AP. Hyperglycemia, hyperinsulinemia, overweight, and high blood pressure in young adults: the Rio de Janeiro Study. Hypertension 1997; 30(Pt 2): 650.

21. Gus M, Moreira LB, Pimentel M, Gleisener AL, Moraes RS, Fuchs FD. Associação de várias medidas de obesidade e hipertensão arterial Arq Bras Cardiol 1998; 70: 111-14.

22. Benseñor IJ, Lotufo PA. Avaliação de indivíduos com alto risco de doença cardiovascular. Experiência da Semana do Coração. Arq Bras Cardiol 1996; 66: 139-41.

23. Jackson R, Barham P, Bills J, et al. Management of raised blood pressure in New Zealand: a discussion document. Br Med J 1993; 307: 107-10. 